\title{
Effect of four grass species on lamb parasitism and growth
}

\author{
J.H. NIEZEN ${ }^{1}$; W.A.G. CHARLESTON ${ }^{2}$, J. HODGSON ${ }^{3}$ and T.S. WAGHORN ${ }^{1}$ \\ ${ }^{1}$ Agresearch, Flock House Agricultural Centre, PB 5452, Bulls \\ ${ }^{2}$ Department of Veterinary Pathology and Public Health, Massey University, Palmerston North \\ ${ }^{3}$ Department of Plant Science, Massey University, Palmerston North
}

\begin{abstract}
Parasite epidemiology and lamb growth were investigated in a study involving four single-species swards (browntop, Yorkshire fog, perennial ryegrass and tall fescue). Lambs were set-stocked from December (weaning) to early June on 1 ha paddocks grazed to a constant height of approximately $5 \mathrm{~cm}$ by varying stock numbers (average 35 lambs/ha). Lambs were weighed and faecal sampled fortnightly and were either "suppression -drenched" fortnightly with ivermectin or "trigger-drenched" when any group mean egg count reached 1500 epg, at which time all groups were drenched. "Trigger-drenched" groups were treated on 4 occasions. At the end of the trial, suppressively drenched lambs on ryegrass were significantly heavier than those on the other grasses $(P<0.01)$. Trigger-drenched lambs on ryegrass were also significantly heavier than those on other grasses $(\mathbf{P}<0.05)$ and those on Yorkshire fog heavier than those on browntop and fescue $(\mathrm{P}<0.05)$. Lambs on browntop and fescue had higher faecal egg counts than those on Yorkshire fog and ryegrass and, despite periodic drenching, clinical parasitism occurred, particularly in animals on browntop. The results suggest that in addition to nutritional effects of different grass species, there were also effects on the levels of parasitism acquired by the lambs in spite of the maintenance of similar sward heights.
\end{abstract}

K eywords: Agrostis tenuis, Festuca arundinacea, gastrointestinal nematodes, Holcus lanatus, Lolium perenne, lamb growth

\section{Introduction}

Most grass cultivars are evaluated in an environment free of gastrointestinal parasites (Lancashire \& Ulyatt 1973) or without the effects of gastrointestinal parasitism being considered (Stevens et al. 1992). With the increasing incidence of anthelmintic resistance being reported (McKenna 1991) and an increasing emphasis on changing grazing management systems to reduce reliance on drenching for parasite control, information is needed as to whether different grasses can affect gastrointestinal nematode larval availability, worm burdens established in lambs and lamb performance. The little work that has been done indicates that larval migration can differ between grass species (Silangwa \& Todd 1964) and that forage type can affect larval survival or establishment of Haemonchus contortus in lambs (Knapp 1964).

This paper reports a 1 -year evaluation of 4 common New Zealand grass species to determine effects on gastrointestinal nematode epidemiology and lamb performance.

\section{$M$ aterials and methods}

Four species of grass, browntop (Agrostis tenuis), Yorkshire fog (Holcus lanatus cv. Massey Basyn), tall fescue (Festuca arundinacea cv. Triumph) and ryegrass (Lolium perenne cv. Grasslands Nui) were established in autumn 1991 at Flock House in 1 ha plots, except for the ryegrass, which was established in a 0.6 ha plot. The following spring the swards were grazed by adult cattle or drenched ewe hoggets to minimise the numbers of gastrointestinal nematode larvae on the pastures. Prior to releasing drenched weaned lambs on to the pastures, they were grazed by ewes with a light worm burden in order to give each paddock an even, light contamination with parasite larvae.

Recently weaned lambs were grazed on the swards for 6 months from December until early June. On each grass species one third of the lambs were suppressively drenched fortnightly with ivermectin (Ivomec ® Merke Sharpe and Dohme) while two thirds were "trigger drenched" when mean faecal egg counts (FECs) reached 1500 eggs per gram of fresh faeces (epg). All lambs were then faecal sampled and drenched with ivermectin at the recommended dose rate. Egg counts were undertaken using a modified McMaster technique.

All pastures were maintained at approximately $5 \mathrm{~cm}$ high by adjusting stocking rates to minimise any effect that pasture height may have on larval ecology and availability. Pasture heights were measured twice per week, using a sward stick, and pasture standing dry matter estimated monthly. Herbage plucks, for counts of third stage gastrointestinal nematode larvae, were taken every second week and the larvae separated from the herbage using a modified Baermann procedure (Vlassoff 1973). 
Prior to the onset of the trial, all the paddocks were sprayed with $2,4 \mathrm{D}$ to eliminate broadleaved weeds and white clover. Urea was applied monthly at a rate of 50 $\mathrm{kg} / \mathrm{ha}$.

Statistical analysis was undertaken using SAS巴 GLM procedures. Faecal egg count data was normalised by square root transformation prior to analysis. Lamb weights were adjusted to common initial body weights.

\section{R esults}

Pasture heights on the 4 plots (Figure 1) were maintained at a height of $5 \mathrm{~cm}$ with some difficulty in the first month as there were problems in matching lamb numbers with pasture growth rates. However, from January until June all swards were maintained within a 4-6 cm range. From December until March, stocking rate on the fescue was higher than on the other treatments (Table 1). On the browntop, stock numbers were maintained at a relatively constant level; ryegrass and fog stocking rates were reduced at the end of March. Only on the fescue was there any patchy grazing.

Figure 1 Monthly average pasture heights for browntop, tall fescue, Yorkshire fog and ryegrass swards when continuously grazed by lambs to a height of $5 \mathrm{~cm}$ for 6 months.

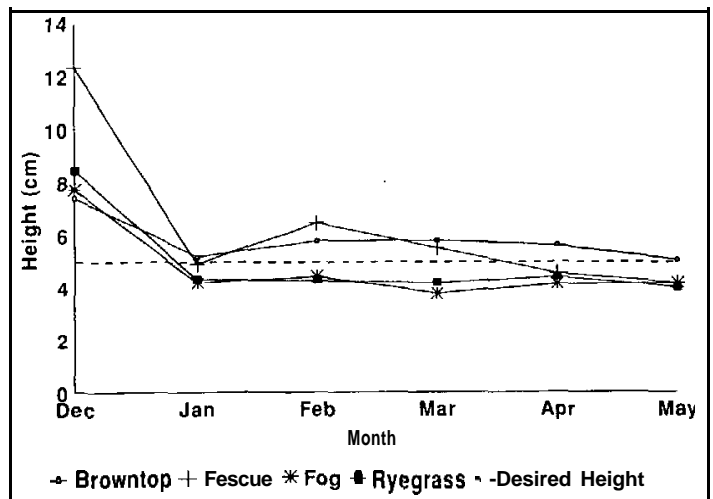

Herbage mass tended to be higher on the browntop than the other treatments during most months. By the end of the trial herbage mass was significantly higher on the browntop than the ryegrass and fescue, fog being intermediate (Table 1).

Although there were some fluctuations in pasture larval counts, overall they tended to increase on all swards during the trial and ended appreciably higher on the browntop than on the other swards (Table 2).

Statistical comparisons were made on the FECs for the trigger-drenched groups before each of the 4 drench treatments (Figure 2). Lambs on fog had significantly lower FECs than lambs on browntop or fescue at all 4 samplings. Lambs on ryegrass had significantly lower FECs than those on fescue and browntop at 3 out of the 4 samplings and generally had similar FECs to those on fog. Egg counts in the suppressively drenched groups were insignificant

At the end of the trial, suppressively drenched lambs on the ryegrass were heavier $(\mathrm{P}<0.05)$ than those on the fescue, fog or browntop, which did not differ

Figure 2 Trigger-drenched lamb mean faecal egg count (FEC) (eggs/g fresh faeces) when continuously grazing browntop, tall fescue, Yorkshire fog or ryegrass to a constant height of $5 \mathrm{~cm}$ for 6 months.

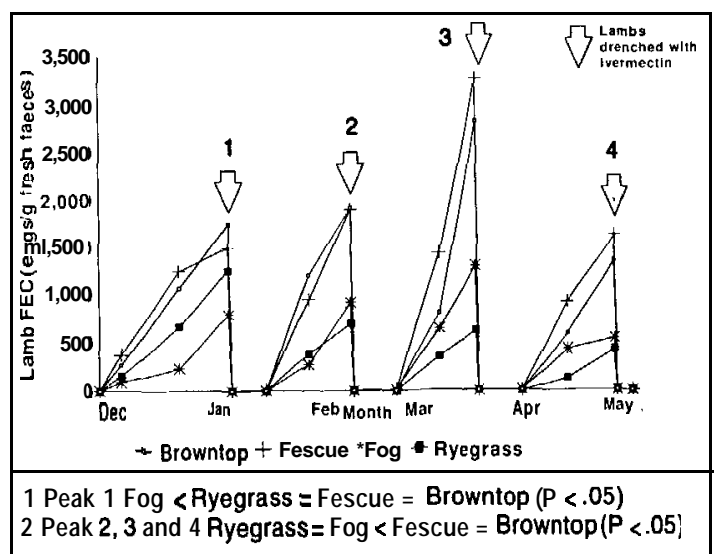

Table 1 Herbage mass (DM) (kg DM/ha) and lamb stocking rate (SR) (lambs/ha) on plots of browntop, tall fescue, Yorkshire fog or ryegrass when continuously stocked and maintained a sward surface height of $5 \mathrm{~cm}$.

\begin{tabular}{|c|c|c|c|c|c|c|c|c|c|c|c|c|}
\hline \multirow[t]{2}{*}{ Treatment } & \multicolumn{2}{|c|}{ December } & \multicolumn{2}{|c|}{ January } & \multicolumn{2}{|c|}{ February } & \multicolumn{2}{|c|}{ March } & \multicolumn{2}{|c|}{ April } & \multicolumn{2}{|c|}{ May } \\
\hline & DM & SR & DM & SR & DM & SR & $\mathrm{DM}$ & SR & $\mathrm{DM}$ & SR & DM & SR \\
\hline Browntop & $3015^{a}$ & 36.6 & $3056^{\text {ab }}$ & 40.5 & $3767^{\prime}$ & 37.3 & $2904^{\prime}$ & 30.7 & $4789^{a}$ & 36.9 & $5863^{a}$ & 36.9 \\
\hline Tall fescue & 3172 & 44.0 & $3438^{a}$ & 46.5 & $2374^{b}$ & 52.0 & $2331^{\mathrm{B}}$ & 53.0 & $2230^{b}$ & 26.0 & $1779^{6}$ & 29.0 \\
\hline Yorkshire Fog & $2786^{a}$ & 33.5 & $2121^{a b}$ & 36.0 & $2785^{\text {ab }}$ & 30.5 & 2344 & 32.0 & $3194^{\mathrm{b}}$ & 19.5 & $5209^{a b}$ & 21.0 \\
\hline $\begin{array}{l}\text { Ryegrass } \\
\text { Pooled SEM }\end{array}$ & $\begin{array}{l}2816^{a} \\
336.7\end{array}$ & 35.9 & $\begin{array}{l}1883^{b} \\
310.4\end{array}$ & 41.7 & $\begin{array}{l}2451^{b} \\
271.0\end{array}$ & 30.0 & $\begin{array}{l}1993^{\circ} \\
263.0\end{array}$ & 30.0 & $\begin{array}{l}2501^{b} \\
252.1\end{array}$ & 24.2 & $\begin{array}{l}1780^{b} \\
160.3\end{array}$ & 26.7 \\
\hline
\end{tabular}

Values in columns with different superscripts differ significantly $\mathbf{P}<0.05$ 
significantly (Table 3). Trigger-drenched lambs were significantly heavier on the ryegrass than on the fog $(\mathrm{P}<0.05)$ which in turn were heavier than lambs on the fescue or browntop. Suppressively drenched lambs were significantly heavier than trigger-drenched lambs $(\mathrm{P}<0.001)$ on the ryegrass, fescue and browntop but not on the fog.

\section{Discussion}

After the first month of the trial, pasture heights were maintained within 4-6 cm throughout the trial, with fog and ryegrass slightly, but consistently, lower than $5 \mathrm{~cm}$, and height declining on fescue near the end of the trial. In the last 2 months, contamination of the ryegrass $\mathrm{sward}$ with fog began to occur. Otherwise the swards were pure and free of broadleaf weeds and clover.

The swards differed markedly in density, and herbage mass was much greater on browntop and fog than on fescue and ryegrass. This is consistent with the sward characteristics of these grasses, fescue and ryegrass being erect, and fog and browntop having a more dense, prostrate morphology. However, herbage mass bore little relationship to lamb production as the ryegrass had the lowest herbage mass but the highest lamb production.

The temporal pattern of third-stage larval numbers on the herbage follows the pattern described by Vlassoff $\&$ Bisset (1991) with peak numbers in the autumn. The higher number on the browntop, when combined with the higher standing herbage DM, indicates a much higher larval population than for the fescue or ryegrass; that on fog was intermediate. The marked difference between browntop and fescue occurred despite the stocking rate on the latter being higher for most of the trial (until April) and the lambs having similar FECs. This suggests that larval development and/or survival is greater on browntop than fescue swards.

The liveweight gain of the suppressively drenched lambs was low, possibly due to the lack of white clover in the sward. Also, the lambs were under a moderate to high larval challenge, which even with regular drenching will reduce lamb growth rates (Coop et al. 1982). However, the pattern of growth rates between ryegrass and browntop agrees with other published results (Lancashire \& Ulyatt 1973). Further grazing trials with Grasslands Roa tall fescue indicates that lamb production is markedly higher (Niezen unpublished) than for Triumph.

Trigger-drenched lambs grazing the fescue and browntop grew poorly, with evidence of clinical parasitism. Several mortalities occurred on the browntop, even though the lambs were drenched when
Table 2 Gastrointestinal nematode third-stage larval counts (nos per kg dry herbage; mean of 2 counts/month) of lambs grazing browntop, tall fescue, Yorkshire fog or ryegrass.

\begin{tabular}{lclcccr}
\hline Treatment & December & January & February & March & April & May \\
\hline Browntop & 1522 & 2997 & 3666 & 4432 & 13445 & 19714 \\
Tall fescue & 2332 & 3666 & 5566 & 1203 & 3409 & 6314 \\
Yorkshire fog & 1157 & 2263 & 964 & 2293 & 7695 & 9329 \\
Ryegrass & 1203 & 9917 & 5016 & 1416 & 6156 & 6401 \\
\hline
\end{tabular}

Table 3 Final liveweights of suppressively or trigger-drenched lambs when continuously grazed on browntop, tall fescue, Yorkshire fog or ryegrass to a constant height of $5 \mathrm{~cm}$ for 6 months.

\begin{tabular}{lccc}
\hline Treatment & $\begin{array}{c}\text { Suppressively } \\
\text { Drenched' }\end{array}$ & $\begin{array}{c}\text { Trigger } \\
\text { Drenched }\end{array}$ & $\begin{array}{c}\text { Contrast of } \\
\text { Suppressive vs } \\
\text { Trigger }\end{array}$ \\
Drenched
\end{tabular}

1 Values in columns with different superscripts differ significantly $P<0.05$

2. ${ }^{*} P<0.01$

mean FECs reached a trigger level similar to that used in other grazing and genetic selection trials (A. Vlassoff pers. comm.). This underlines the difficulty of using FECs as the sole indicator of requirement to trigger drench. Other trials show that lambs with a similar if not higher FEC but fed tannin-containing crops can attain growth rates of up to $230 \mathrm{~g} /$ day (Niezen et al. 1993). This indicates that feed quality and/or secondary compounds in the plants can have an important role to play in determining parasitised lamb performance.

Trigger-drenched lambs on the fog had slightly (non-significant) lower final weights than the suppressively drenched lambs, in contrast to lambs on the other grasses where there was a wide divergence in liveweights between suppressive and trigger-drenched groups. A similar pattern has been observed in later trials (Niezen unpublished).

\section{Conclusions}

The results indicate that there is a significant effect of pasture species on parasitiscd lamb performance and on larval availability. The extent to which this can or will influence grazing management decisions is still unknown. Whether the patterns of lamb performance would be the same if clover were introduced into the swards remains the subject of future study. 


\section{ACKNOWLEDGEMENTS}

This project was funded by the Meat Research and Development Council (MRDC) for which the authors are grateful. Thanks also goes to Sue Wilson for undertaking all the faecal egg and larvae counts and to C. Ridland, J. Ransom and W. Stiefel for their cooperation.

\section{REFERENCES}

Coop, R.L.; Sykes, A.R.; Angus, K.W. 1982. The effect of three levels of intake of $\mathbf{0}$ stertagia circumcincta larvae on growth rate, food intake and body composition of growing lambs. Journal of agricultural science, Cambridge 98: 247-255.

Knapp, S.E. 1964. Relationship of different species of forage to the survival and infectivity of Haemonchus contortus in lambs. Journal of parasitology 50: 144-148.

Lancashire, J.A.; Ulyatt. M.J. 1973. Liveweight gains by sheep grazing browntop or perennial ryegrass. Proceedings of the New Zealand Grassland Association 54: 143-146.
McKenna, P.B. 1991. Update on drench resistance. Proceedings of the 21 st Seminar of the Sheep and Beef Cattle Society of the New Zealand Veterinary Association. 55-60.

Niezen, J.H.; Waghorn, T.S.; Waghorn, G.C.; Charleston, W.A.G. 1993. Internal parasites and lamb production - a role for plants containing condensed tannins?. Proceedings of the New Zealand Society of Animal Production 53: 235-238.

Silangwa, S.M.; Todd, A.C. 1964. Vertical migration of Trichostrongylid larvae on grasses. Journal of parasitology 50: 278-285.

Stevens, D.R.; Baxter, G.S.; Stewart, A.; Casey, M.J.; Miller, K.B. 1992. Grasslands Kara cocksfoot: a productive cultivar under lax grazing. Proceedings of the New Zealand Grassland Association 54: 143146.

Vlassoff, A. 1973. Seasonal incidence of infective trichostrongyle larvae on pasture grazed by lambs. New Zealand journal of experimental agriculture 1: 293-301

Vlassoff, A.; Bisset, S.A. 1991. Basic principles of parasite epidemiology. Proceedings of the 21st Seminar of the Sheep and Beef Cattle Society of the New Zealand Veterinary Association. 5- 12. 